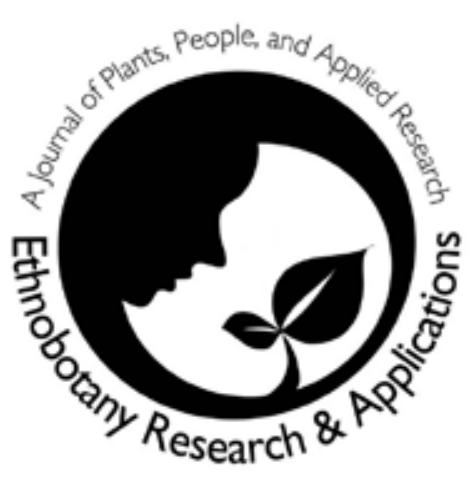

\title{
From Garden to Market? The cultivation of native and introduced medicinal plant species in Cajamarca, Peru and implications for habitat conservation
}

\author{
Research
}

\author{
Rainer W. Bussmann, Douglas Sharon and Jennifer Ly
}

\begin{abstract}
Large amounts of medicinal plants are sold in the markets of Trujillo and Chiclayo, two cities on the north coast of Peru. However, a large percentage of this material comes from the Peruvian highlands, most notably from the Department of Cajamarca. Although prior studies indicate that at least some material, mostly introduced species, is grown in home-gardens on the coast, the origin of the vast bulk of the plants was unclear. The present study reports on medicinal plants grown, collected and sold in the Cajamarca region. Only 42 plant species, 34 of them indigenous, were sold in the local markets. In contrast, 76 species (25 introduced, 51 indigenous) were found in local gardens or were cultivated by vendors. Of these however, only five species were commonly cultivated in the homegardens studied, and 11 were grown by plant vendors. All but three of the commonly cultivated species were introductions. Contrary to the initial assumption, increasing plant demand in the large coastal markets has not led to significant cultivation of medicinal plants in home-gardens. The vast bulk of the plant material sold in the markets of Northern Peru represents plants collected in the wild. No data are available as to whether this massive harvest is sustainable or not.
\end{abstract}

\section{Resumen}

Cantidades grandes de plantas medicinales se venden en los mercados d Trujillo y Chiclayo, dos ciudades en la costa norte del Perú. Sin embargo, un porcentaje grande de este material viene de la sierra peruana, principalmente del departamento de Cajamarca. Aunque estudios previos indican que por lo menos una porción del material, mayormente especies introducidas, es cultivado en jardines caseros en la costa, el origen de la vasta mayoría de las plantas no fue muy claro. El estudio actual reporta sobre las plantas medicinales cultivadas, coleccionadas y vendidas en la región de Cajamarca. Solamente 42 especies, de las cuales 34 son indigenas, se vendieron en los mercados locales. En contraste, 76 especies $(25$ introducidas, 51 indígenas) fueron ubicadas en los jardines locales o cultivadas por los vendedores. De estos, sin embargo, solamente cinco especies fueron cultivadas comúnmente en los jardines caseros estudiados, y 11 fueron cultivadas por los vendedores de plantas. Solamente tres de las especies comúnmente cultivadas no fueron introducidas. Al contrario de la presunción inicial, la demanda incrementada para plantas en los mercados grandes de la costa no se ha resultado a una cultivación significante de plantas medicinales en los jardines caseros. La vasta mayoría de las plantas vendidas en los mercados del Perú Septentrional representa plantas coleccionadas en un estado silvestre. No hay datos disponibles para indicar si esta cosecha masiva es sostenible o no.

\section{Introduction}

Studies of home-gardens experienced a boom in the 1980s and 90s (Eyzaguirre \& Linares 2004). Home-gardens are often cited as important reservoirs for crop germplasm and as plant domestication sources (Alcorn 1992,

\section{Correspondence}

Rainer W. Bussmann, William L. Brown Center for Plant Genetic Resources, Missouri Botanical Garden P.O. Box 299, St. Louis, MO 63166-0299, U.S.A. rainer.bussmann@mobot.org Douglas Sharon, 2328 Dolphin Dr., Richmond, CA 94804, U.S.A.

Jennifer Ly, University of California at Berkeley, College of Natural Resources, Department of Forestry and Natural Resources, 245 Mulford, Berkeley, CA 94720-3114, U.S.A.

jennifer_ly@berkeley.edu

Ethnobotany Research \& Applications 6:351-361 (2008)

Published: November 14, 2008 
Merrick 1992, Smith 1996). Many studies indicate that these gardens are mostly sources of food, but that medicinal plants play only a marginal role in production (Colunga-García Marín \& Zisumbo-Villarreal 2004, Coomes \& Ban 2004). Dialogue with medicinal plant vendors and inventories of their stands in the markets of Chiclayo (Modelo \& Moshoqueque) and Trujillo (Mayorista) showed that a significant amount of the medicinal plants for sale comes from the Cajamarca highlands. The cultivation of medicinal plants may help to curb the potential losses caused by destruction of natural habitats. Bussmann and Sharon (2006) determined that many introduced medicinal plant species are cultivated in fields and gardens on the coast, but that the majority of native medicinal plants are collected in the wild. Traditional medicine is experiencing increasing demands from a Peruvian as well as global perspective (Bussmann \& Sharon 2006).

Studies from other regions of Latin America (e.g., Major et al. 2005, Shanley \& Rosa 2004) indicate that market demand influences the composition of farms and homegardens. Based on this assumption the authors expected to encounter extensive cultivation of medicinal plants in gardens of the source region.

This study examines the market for fresh medicinal plants in the city of Cajamarca and two gardens located in the surrounding highlands of Cajamarca. It focuses on native and introduced taxa available in the market, providing insight into which plants individuals typically use for medicinal purposes. The study additionally examines whether introduced and native species available in the market are cultivated or collected in the wild. Inventories of medicinal plant species cultivated in the gardens and examination of purpose and methods of cultivation provide insight into the treatment of native and introduced medicinal plant species.

\section{Materials and Methods}

This study focuses on the medicinal plants native to the Cajamarca highlands and introduced species that are used extensively in the region. The medicinal plant vendors in the market were categorized as follows:

1. Specialized vendors - These vendors had at least six different medicinal plant taxa (species or varieties of species). Medicinal plants were their primary and usually their only products. All plant material was fresh.

2. Non-specialized vendors - These vendors had two to five different medicinal plant taxa (species or varieties of species). They often sold medicinal plants alongside vegetables or plants that are used as condiments. All plant material was fresh.

Excluded were herbalists who had stands with more than 50 specialized products, which usually included fresh, dry and packaged plants, bottled liquids, perfumes, and other materials of curative value. Their plants customarily come from coastal, mountainous, and tropical regions of Peru. Also excluded were vendors of bottled liquids of curative value.

The study was conducted in July 2007 at the Revelia Pérez market in Cajamarca, where inventories of the medicinal plants for sale by each non-specialized vendor were recorded. The first step was to explain the purpose of the study, and to obtain oral prior informed consent from all participants. In addition, observations of the non-specialized vendors and medicinal plants available were made to verify that the inventories taken on the three prior days provided an accurate representation of the medicinal plants available by non-specialized vendors throughout the week. On the two days of the week that specialized vendors came to the market, inventories of the medicinal plants that they sold were recorded. Informal dialogue with the non-specialized and specialized vendors provided information about where they came from and whether the plants they sold had been cultivated, collected in the wild, or bought from another individual.

Two garden case studies were conducted in the communities of Chigdén and Higuerón in the San Juan district of Cajamarca (Figure 1). The case studies consisted of

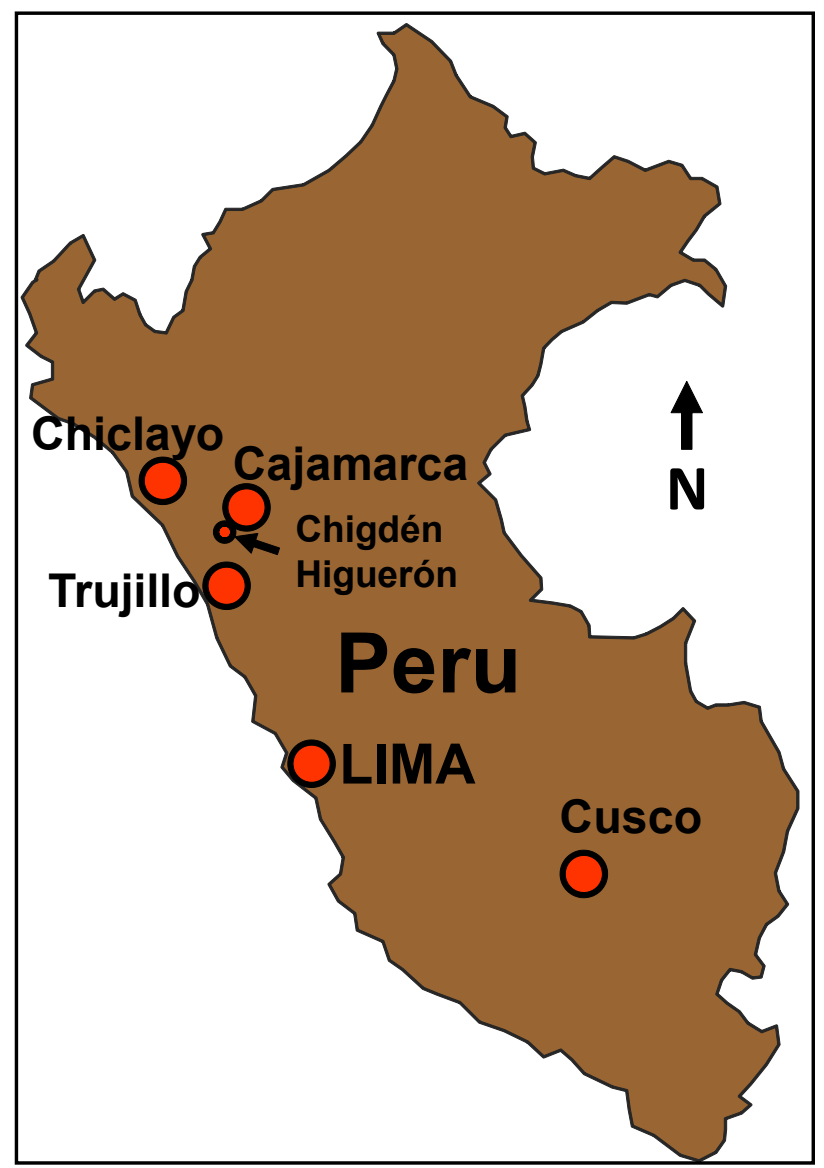

Figure 1. Study area in the Cajamarca highlands, Peru. 


\section{Bussmann et al. - From garden to market? The cultivation of native and introduced medicinal plant species in Cajamarca, Peru}

inventory of the medicinal plant species grown in homegardens, observation of use of space and species arrangement, and dialogue with the families about management and other income-generating activities. Vouchers of all specimens were deposited at the Herbario Truxilliensis (HUT, Universidad Nacional de Trujillo), and Herbario Antenor Orrego (HAO, Universidad Privada Antenor Orrego Trujillo). In order to recognize Peru's rights under the Convention on Biological Diversity, especially with regard to the conservation of genetic resources in the framework of a study treating medicinal plants, the identification of the plant material was conducted entirely in Peru. No plant material was exported in any form whatsoever. The nomenclature of plant families, genera, and species follows the Catalogue of the Flowering Plants and Gymnosperms of Peru (Brako \& Zarucchi 1993). Species were identified using the available volumes of the Flora of Peru (Macbride 1936-81), and reference material in the herbaria HUT and HAO.

\section{Results}

\section{Specialized and non-specialized vendors in the Revelia Pérez market}

The Revelia Pérez market is an outdoor marketplace in the city of Cajamarca operating from approximately 8:00am to $3: 00 \mathrm{pm}$ daily. Vendors sell vegetables, fruits, meats, medicinal plants, fresh livestock feed, household products, and accessories. The majority of the medicinal plant vendors were campesinas, or peasant women, who came into the city from the surrounding highlands.

Non-specialized vendors dominated the medicinal plant market. Twelve of 20 non-specialized vendors sold medicinal plants exclusively, while the remaining eight sold medicinal plants as well as plants to be used as condiments, or primarily sold vegetables or meat with a small amount of medicinal plants for sale. There were no more than five to six bundles of different plant species per stand. However, the average number of species per vendor was three. For example, one particular vendor might sell manzanilla, romero and culantro. Twenty distinct medicinal plants were observed among all non-specialized vendors over the course of a week, seven of which were introduced species and 13 of which were native. However, the most common plants were manzanilla dulce, orégano, culantro, ruda and perejil (Figure 2). Other plants observed were alcachofa, cedrón, clavel, cola de caballo, hierba luisa, llantén, maca, matico, menta, muña, paico, romero, rosa, tomate del campo and toronjil.

On two determined days of each week, specialized vendors sold medicinal plants in a localized area within the

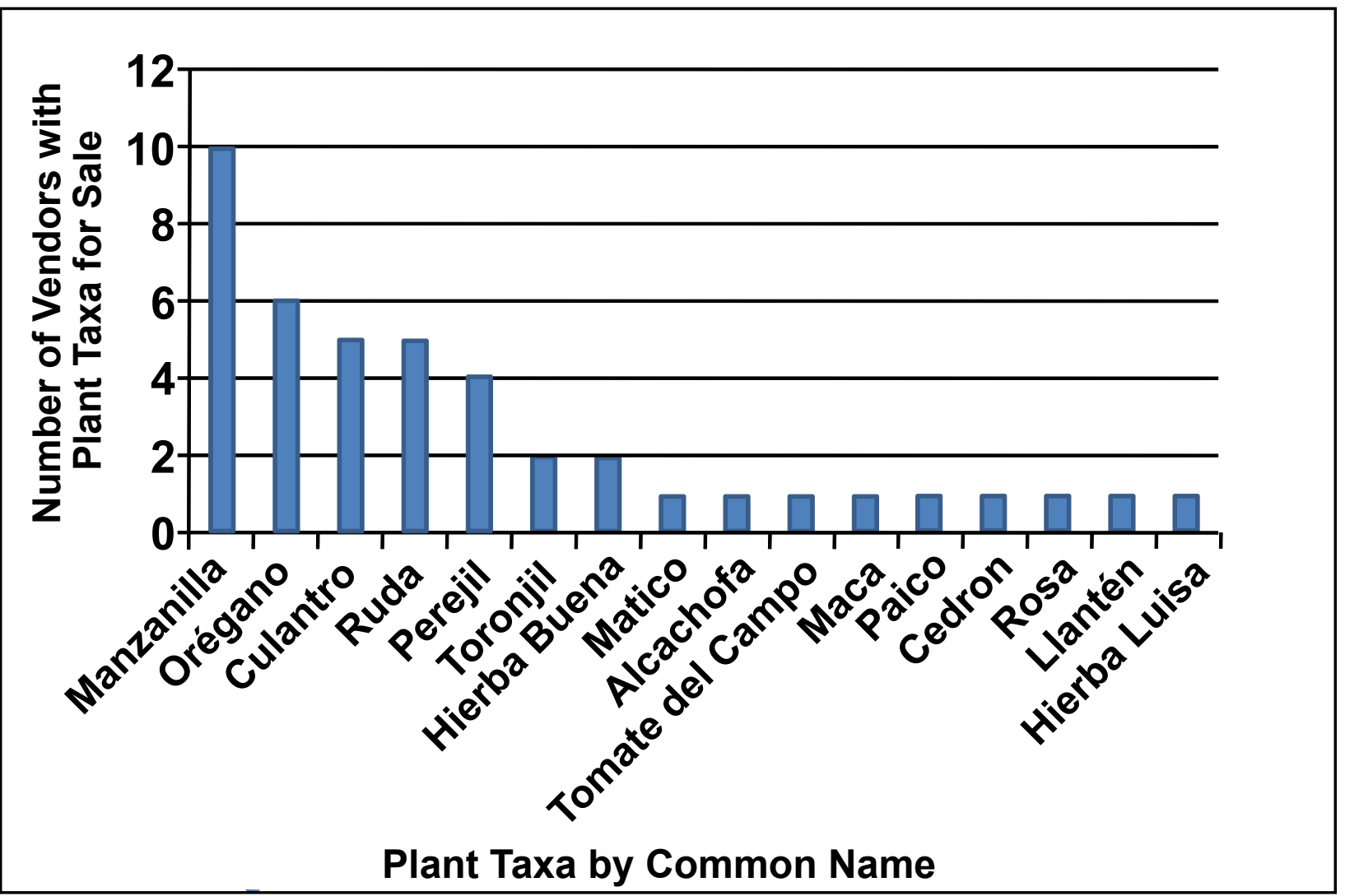

Figure 2. Typical daily selection among non-specialized vendors at the Revelia Pérez market near Cajamarca, Peru. 
Revelia Pérez market from 8AM to approximately 12PM. There were no more than eight specialized vendors on a given day. Vendors typically arrived with a large quantity of one to three plant species. Most of these vendors sold what that they had in bulk to other vendors in agreements that appeared to have been previously arranged. The primary purpose of this gathering appeared to be for vendors to buy and sell medicinal plants in bulk from and to other vendors, which most vendors would then sell in larger markets, such as in those of Chiclayo (Modelo and Moshoqueque). Specialized vendors appeared to aim at diversifying their medicinal plant selection by purchasing from other vendors with the goal of having a supply of all of the medicinal plants available. While most vendors sold small quantities of their medicinal plants directly to the public while making bulk sales and purchases, selling directly to the Cajamarca public was the primary purpose of only a minority of specialized vendors on any given day. Many of these vendors collected in the wild a portion of the plant species that they.
Specialized vendors carried a wide selection of medicinal plants (see Table 1). Fourty-two distinct medicinal plants were observed among all specialized vendors on two days, eight of which were introduced and 34 of which were native. Vendors said that most of these plants had been collected in the wild and are only found in particular areas of the highlands. A specialized vendor who collected medicinal plants in the wild explained that plants such as vira vira and escorcionera came only from specific areas in the highlands. Dialogue with specialized and non-specialized vendors indicated that many vendors bought medicinal plants from other individuals to sell in the marketplace and that few individuals cultivated plants. One specialized vendor, who cultivated small amounts of ruda and romero, when asked why she did not cultivate any of the native species that she collected in the wild, explained that cultivation was labor-intensive and that it was easier to purchase medicinal plants from other vendors in the marketplace.

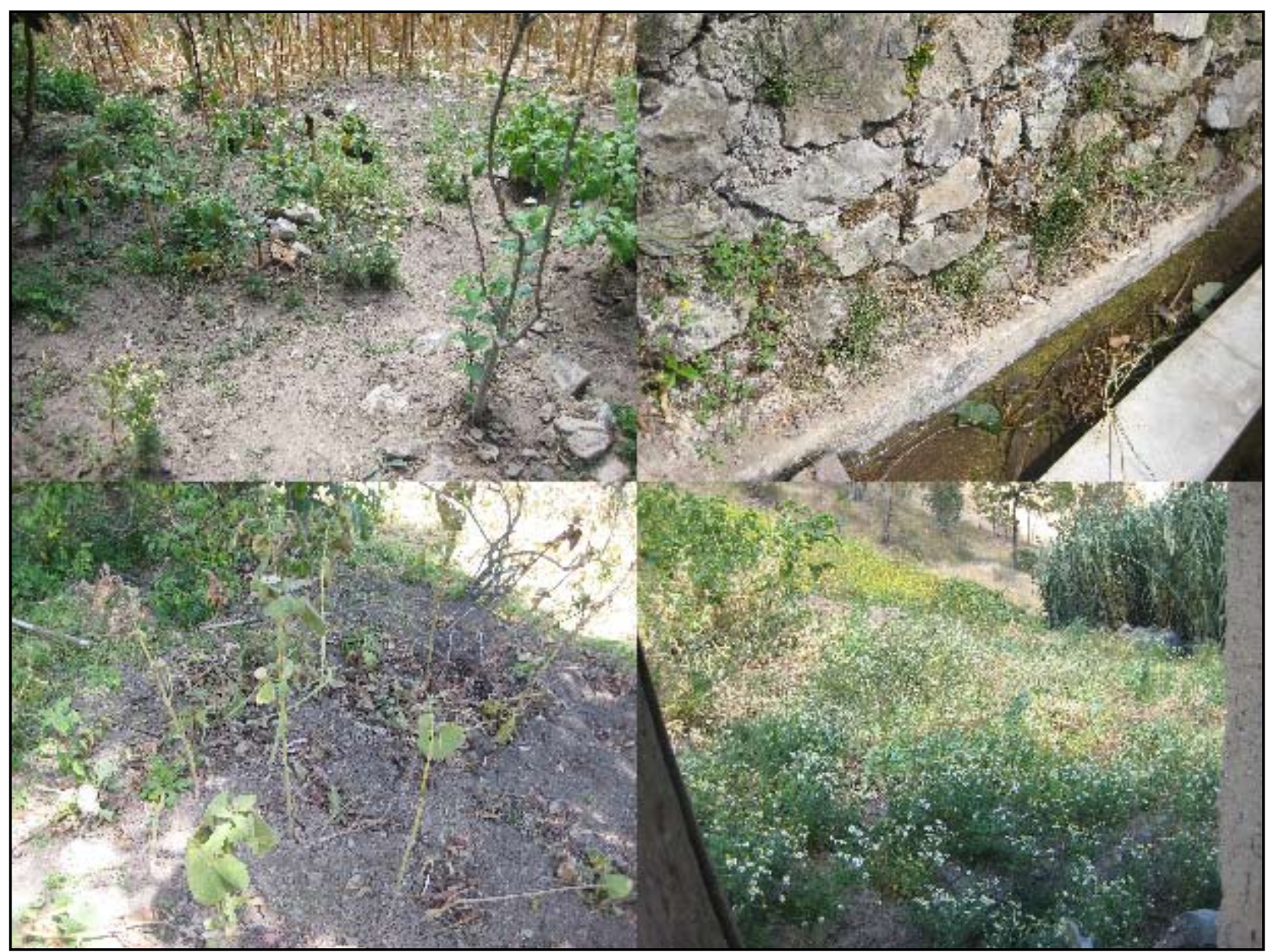

Figure 3. Chigdén garden study. Top left: garden space adjacent to corn cultivation. Bottom left: yacon garden space. Top right: spontaneous growth of cola de caballo. Bottom right: Growth of manzanilla adjacent to the house and field of mostaza in the background. 


\section{Bussmann et al. - From garden to market? The cultivation of native and introduced medicinal plant species in Cajamarca, Peru}

\section{Garden study, Chigdén}

The family-owned property in Chigdén, including the house, gardens and crop fields was approximately 7000 $\mathrm{m}^{2}$. The main use of space at the residence was for potato and corn production. There were two loosely connected gardens located in areas immediately surrounding the house that contained interspersed fruit- and vegetable-bearing plants and trees, medicinal plants, and plants of ornamental and medicinal value. The garden space was approximately $700 \mathrm{~m}^{2}$. The soil generally appeared to have been thoroughly prepared only in areas of crop production.

Large quantities of manzanilla grew fairly unmanaged in an area immediately adjacent to the house. Mostaza grew unmanaged in a field adjacent to the manzanilla farther away from the house. In addition to mostaza and manzanilla, the other plant species traditionally used for medicinal value grown in quantities large enough to be sold in significant quantities were yacon and margarita. Yacon was the only plant in the garden observed to have been planted in rows and was planted in a space of approximately $25 \mathrm{~m}^{2}$ (Figure 3 ).

Vegetable- and fruit-bearing trees were randomly dispersed and included berengena, granadilla, limón, guava, higo and rocoto. The medicinal plants present in the garden did not appear to be planted with any particular arrangement. Many appeared to have grown spontaneously. For example, cola de caballo grew inbetween rocks near a source of water (Figure 3 ) and cerraja and amor seco grew randomly in plants of one or two. Many introduced plants were observed (see Table 1). The growing substrate in the garden was generally dry and compacted and did not appear to have been extensively prepared. Introduced species, particularly culantro, perejil, manzanilla and Ilantén, were randomly dispersed throughout the garden. Most species in the garden existed in enough quantities for household consumption but were not for sale in significant quantities. Dialogue with one of the family members showed that manzanilla was occasionally purchased from a neighbor to be sold in the Moshoqueque marketplace in Chiclayo.

\section{Garden study, Higuerón}

The family-owned property observed in Higuerón, including the house, garden and crop fields was approximately $7000 \mathrm{~m}^{2}$. The main use of space at the residence was for corn, wheat, potato, cauliflower and sweet potato cultivation. The garden was located in an area adjacent to the house in a space of approximately $400 \mathrm{~m}^{2}$. Plants and trees bearing foodstuffs included lemon, lettuce, beet, bean, berengena, cañas, chirimoya, palta, pepino and plátano. The garden contained rows of somewhat interspersed fruit- and vegetable-bearing plants and trees and medicinal plants.
Near the house was a field of bisnaga, which was customarily cultivated during fallow periods of wheat, sweet potato and potato cultivation. During periods of food-crop cultivation, cow and sheep manure was customarily used as fertilizer. Chemical fertilizer was sometimes used when needed; however, dialogue with a neighbor showed that farmers in the area generally attempt to avoid using chemical fertilizer because it changes the quality of the crop.

Toronjil was grown in rows in the garden in a space of approximately $75 \mathrm{~m}^{2}$ and was the only medicinal plant in the garden that could be harvested for sale in significant quantities. The soil had been ploughed and enriched. A family member explained that toronjil and bisnaga were regularly sold in bulk to a friend who walked an hour and a half through the highlands to the residence in order to harvest them. He then sold these medicinal plants in the Moshoqueque Market in Chiclayo.

Aside from toronjil, the arrangement of medicinal plant species did not follow any specific planting pattern, but was rather disorganized. Medicinal plants included alcachofa, cerraja, culantro, hierba santo, lancetilla, Ilantén, mala hierba, malva, perejil, ruda, verbena and yacón (Table 1) which were interspersed among rows of bean, lettuce, and beet plants. Many appeared to have grown spontaneously.

\section{Discussion}

Data on the medicinal plant selection available from nonspecialized vendors show a prevalence of introduced species in the marketplace. The population of Cajamarca is mostly Mestizo, and the belief that "wild" plants are more potent than cultivated species, often encountered in indigenous populations, was not observed in the region.

The majority of medicinal plant species sold by non-specialized vendors were introduced species. Although a variety of native species were also available among nonspecialized vendors, the medicinal plants that recurred among non-specialized vendors were manzanilla dulce, orégano, culantro, ruda and perejil, all of which are introduced species with the exception of ruda. While Cajamarca is a region rich in native medicinal plant species, it appears that fresh plants from the highlands are not in high demand in the city of Cajamarca. The specialized vendors of medicinal plants only appeared at the market on two days of the week, and the majority had the primary purpose of buying and selling in bulk among themselves. These vendors generally preferred to sell at the Moshoqueque marketplace in Chiclayo. Although there is a significant amount of medicinal plant collection in the Cajamarca highlands, introduced species dominate as the ingredients of homemade remedies.

The inventory of medicinal plants available from specialized and non-specialized vendors and inquiries about 
Table 1. Introduced and native medicinal plant species cultivated in gardens and available in the Revelia Pérez market, Peru.

\begin{tabular}{|c|c|c|c|c|c|c|}
\hline & \multicolumn{3}{|c|}{ Key to Gardens } & \multicolumn{3}{|c|}{ Key to Vendors } \\
\hline & \multicolumn{3}{|c|}{ Cultivated in significant quantities } & \multicolumn{3}{|c|}{ Cultivated in significant quantities } \\
\hline & \multirow{2}{*}{\multicolumn{3}{|c|}{ Random and dispersed in small quantities }} & \multicolumn{3}{|c|}{ Random and dispersed in small quantities } \\
\hline & & & & \multicolumn{3}{|c|}{ Cultivated and/or collected } \\
\hline \multirow[t]{2}{*}{ Scientific Names } & & \multirow{2}{*}{$\begin{array}{l}\text { Common } \\
\text { Names }\end{array}$} & \multicolumn{2}{|c|}{ Gardens } & \multicolumn{2}{|c|}{ Vendors } \\
\hline & & & Chigden & Higuerón & $\begin{array}{c}\text { Non- } \\
\text { Specialized }\end{array}$ & Specialized \\
\hline \multicolumn{7}{|l|}{ Introduced Species } \\
\hline \multicolumn{7}{|l|}{ APIACEAE } \\
\hline Coriandrum sativum $\mathrm{L}$. & & Culantro & & & & \\
\hline Foeniculum vulgare Mill. & & Hinojo & & & & \\
\hline $\begin{array}{l}\text { Petroselinum crispum (Mill.) } \\
\text { Nyman ex A.W. Hill }\end{array}$ & & Perejil & & & & \\
\hline \multicolumn{7}{|l|}{ APOCYNACEAE } \\
\hline Nerium oleander L. & & Rosa & & & & \\
\hline \multicolumn{7}{|l|}{ ASTERACEAE } \\
\hline Artemisia absinthium L. & & Ajenco & & & & \\
\hline Chrysanthemum leucanthen & רum L. & Margarita & & & & \\
\hline Cynara cardunculus L. & & Alcachofa & & & & \\
\hline Matricaria recutita L. & & $\begin{array}{l}\text { Manzanilla } \\
\text { Dulce }\end{array}$ & & & & \\
\hline Sonchus oleraceus L. & & Cerraja & & & & \\
\hline Taraxacum officinale F.H. W & gg. & Diente de Leon & & & & \\
\hline \multicolumn{7}{|l|}{ BORAGINACEAE } \\
\hline Borrago officinalis L. & & Borraja & & & & \\
\hline \multicolumn{7}{|l|}{ BRASSICACEAE } \\
\hline Brassica napus L. & & Mostaza & & & & \\
\hline Capsella bursa-pastoris (L.) & Medik. & Bolsa de Pastor & & & & \\
\hline Rorippa nasturtium-aquaticu & $m($ L.) Hayek & Berros & & & & \\
\hline \multicolumn{7}{|l|}{ CARYOPHYLLACEAE } \\
\hline Dianthus caryophyllus L. & & Clavel & & & & \\
\hline \multicolumn{7}{|l|}{ FABACEAE } \\
\hline Trifolium repens $\mathrm{L}$. & & Trebol & & & & \\
\hline \multicolumn{7}{|l|}{ LAMIACEAE } \\
\hline Melissa officinalis L. & & Toronjil & & & & \\
\hline Mentha spicata L. & & Menta & & & & \\
\hline Origanum vulgare L. & & Oregano & & & & \\
\hline Rosmarinus officinalis L. & & Romero & & & & \\
\hline \multicolumn{7}{|l|}{ LINACEAE } \\
\hline Linum usitatissimum L. & & Linaza & & & & \\
\hline \multicolumn{7}{|l|}{ MYRTACEAE } \\
\hline Eucalyptus globulus Labill. & & Eucalipto & & & & \\
\hline
\end{tabular}


Bussmann et al. - From garden to market? The cultivation of native and
introduced medicinal plant species in Cajamarca, Peru

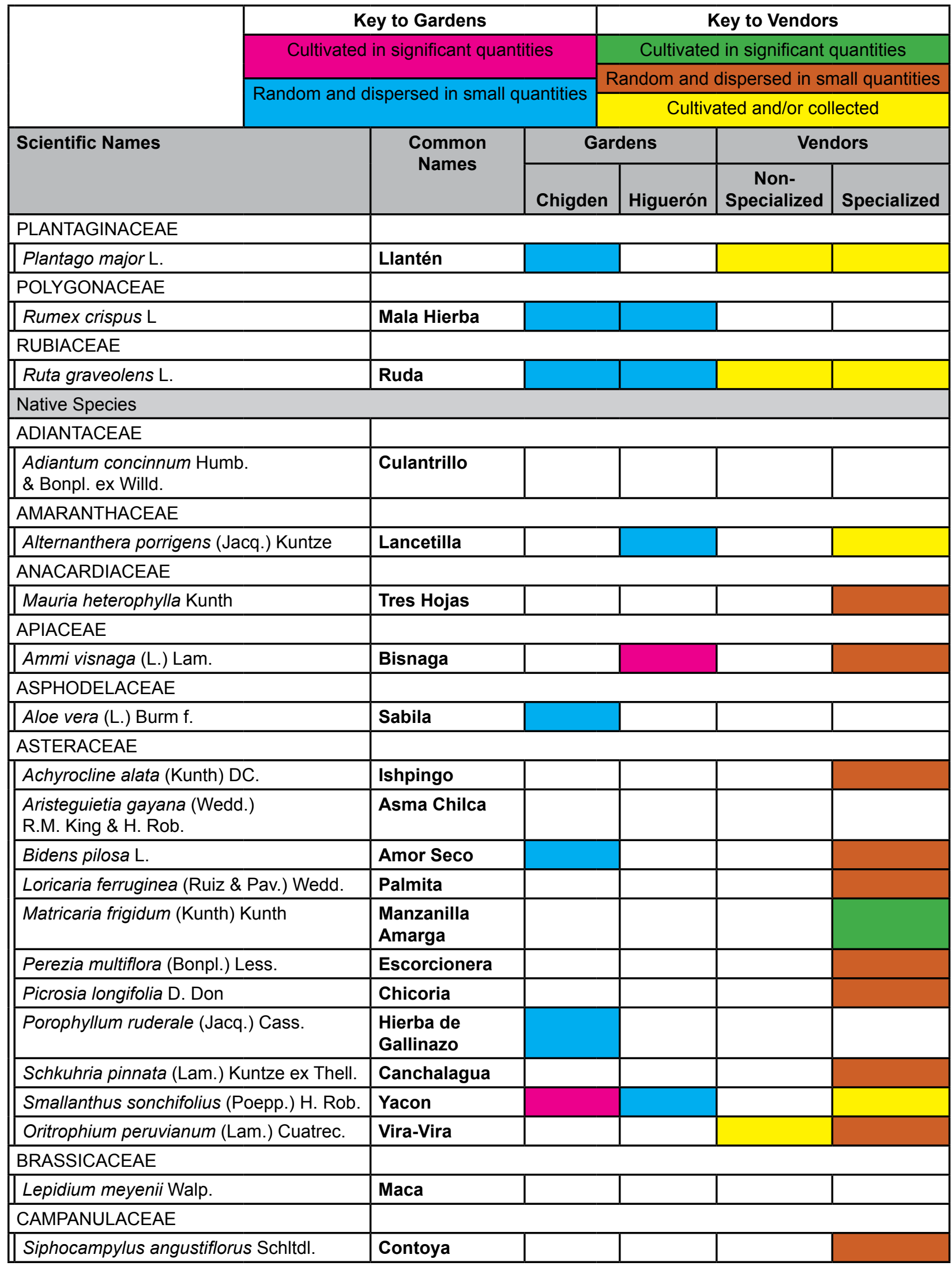




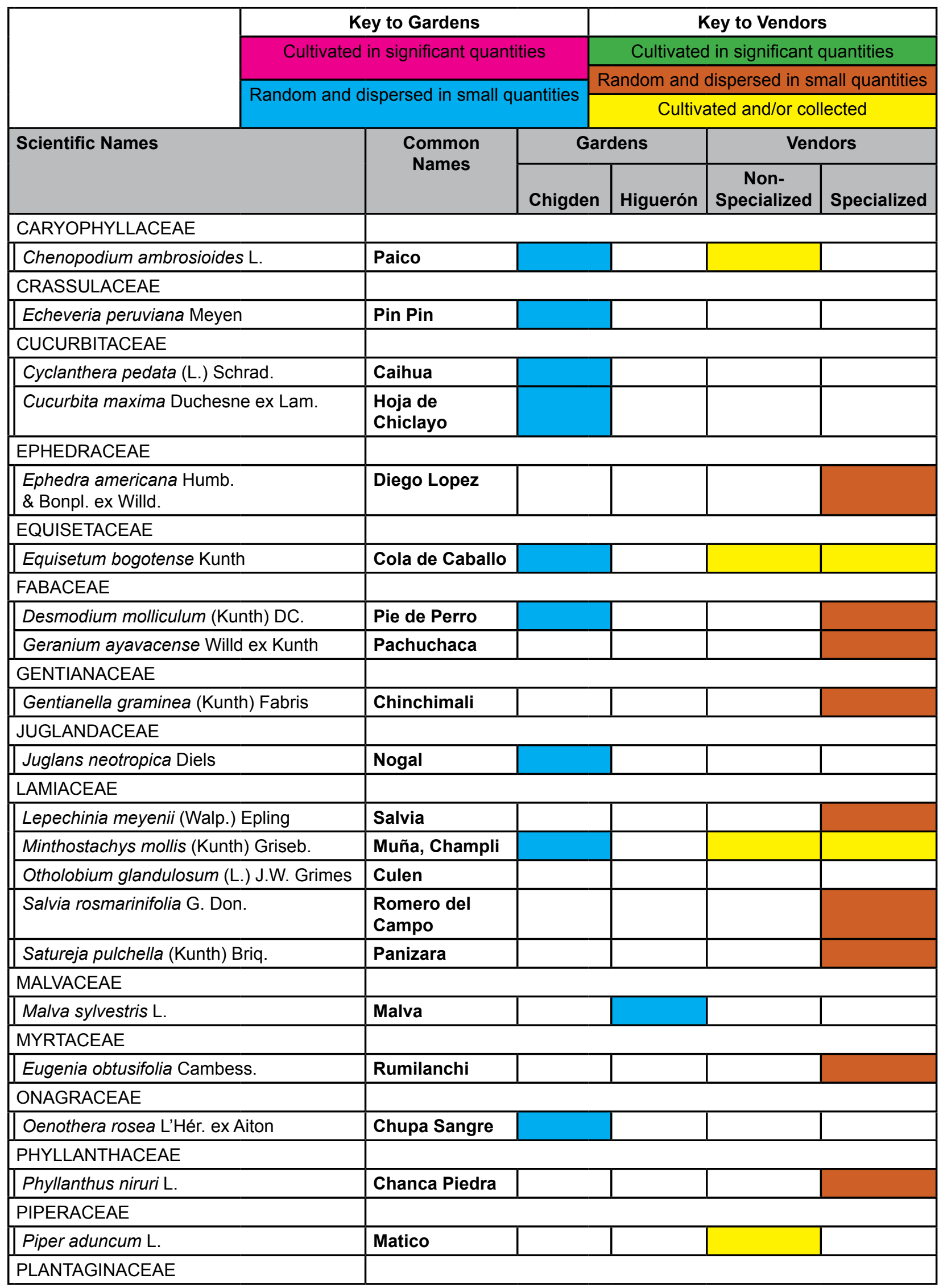




\section{Bussmann et al. - From garden to market? The cultivation of native and introduced medicinal plant species in Cajamarca, Peru}

\begin{tabular}{|c|c|c|c|c|c|c|}
\hline & \multicolumn{3}{|c|}{ Key to Gardens } & \multicolumn{3}{|c|}{ Key to Vendors } \\
\hline & \multicolumn{3}{|c|}{ Cultivated in significant quantities } & \multicolumn{3}{|c|}{ Cultivated in significant quantities } \\
\hline & \multirow{2}{*}{\multicolumn{3}{|c|}{ Random and dispersed in small quantities }} & \multicolumn{3}{|c|}{ Random and dispersed in small quantities } \\
\hline & & & & \multicolumn{3}{|c|}{ Cultivated and/or collected } \\
\hline \multirow{2}{*}{\multicolumn{2}{|c|}{ Scientific Names }} & \multirow{2}{*}{$\begin{array}{l}\text { Common } \\
\text { Names }\end{array}$} & \multicolumn{2}{|c|}{ Gardens } & \multicolumn{2}{|c|}{ Vendors } \\
\hline & & & Chigden & Higuerón & $\begin{array}{c}\text { Non- } \\
\text { Specialized }\end{array}$ & Specialized \\
\hline Plantago linearis Kunth & & Llantén & & & & \\
\hline \multicolumn{7}{|l|}{ POACEAE } \\
\hline Pennisetum sp. & & Chacato & & & & \\
\hline Cymbopogon citratus (DC.) $\varsigma$ & Stapf & Hierba Luisa & & & & \\
\hline \multicolumn{7}{|l|}{ POLYGALACEAE } \\
\hline Monnina pterocarpa Ruiz \& $\mathrm{F}$ & Pav. & Mancosechawe & & & & \\
\hline \multicolumn{7}{|l|}{ POLYPODIACEAE } \\
\hline Polypodium crassifolium $\mathrm{L}$ & & Calaguala & & & & \\
\hline \multicolumn{7}{|l|}{ PROTEACEAE } \\
\hline Oreocallis grandiflora (Lam.) & R.Br. & $\begin{array}{l}\text { Popa, } \\
\text { Cucharilla }\end{array}$ & & & & \\
\hline \multicolumn{7}{|l|}{ ROSACEAE } \\
\hline Geum peruvianum Focke & & Valeriana & & & & \\
\hline \multicolumn{7}{|l|}{ SOLANACEAE } \\
\hline Cestrum auriculatum L'Hér. & & Hierba Santa & & & & \\
\hline Nicotiana tabacum L. & & Tabaco & & & & \\
\hline Physalis peruviana L. & & $\begin{array}{l}\text { Tomate del } \\
\text { Campo }\end{array}$ & & & & \\
\hline \multicolumn{7}{|l|}{ VERBENACEAE } \\
\hline Aloysia triphylla (L'Hér.) Brittc & & Cedron & & & & \\
\hline Verbena littoralis Kunth & & Verbena & & & & \\
\hline
\end{tabular}

where their plants came from provided a fairly clear delineation showing that introduced species are cultivated and native species are collected in the wild (Table 1). The exception among introduced species is eucalipto, which vendors said was collected in the wild. How eucalipto could be collected in the "wild" is explained by the reforestation efforts in the highlands using eucalipto. Responses of vendors were consistent in indicating that most native medicinal plant species were not cultivated and were collected in the wild. These include native species such as vira vira, escorcionera and Diego López. Exceptions among native species were toronjil and bisnaga, which were cultivated in the garden and field located in Higuerón.

The gardens at Chigdén and Higuerón were found to be typical examples for the cultivation of medicinal plant species in Cajamarca. While many native species were found in the gardens visited in Chigdén and Higuerón, it is crucial to note that most of these species grew spontaneous- ly in minute quantities and did not constitute cultivation of significant importance in terms of potential for sale in the marketplace. It is even questionable whether many of the species found in the gardens were employed in the household as material for homemade remedies. The selection of medicinal plants and their sale in small quantities often with other goods of alimentary value by non-specialized vendors indicate that individuals usually engage in a variety of activities as primary income-generating tactics, incidentally cultivating small amounts of medicinal plants. In other cases, individuals purchase small quantities of medicinal plant species from other vendors in the marketplace to diversify product variety.

This study has provided a glimpse into the buying and selling interactions among market vendors and suppliers revealing that they are more complex than anticipated. Dialogue and observation of individuals, including both types of vendors who arrived with large amounts of one or two species to sell to other vendors, substantiated to a certain 
degree the view that few individuals cultivate or collect plants and that most purchase from others. In any case, specialized and non-specialized vendors acquire much of the medicinal plant material that they sell from other vendors in the marketplace.

Dialogue with vendors in the marketplace and the Chigdén and Higuerón garden studies show that native species are seldom cultivated. Considering the distances that are traveled to collect medicinal plants from their native habitats in specific areas of the highlands, it becomes important to ask why individuals do not cultivate certain native plant species. There are three possible reasons: 1) A plant species grows in abundance in the highlands, making collection relatively efficient 2) A plant species has rigid habitat requirements and does not flourish when displaced from its native habitat, or 3) Cultivation includes space and time requirements that individuals are not willing to invest. Advantages to cultivation include a localized site and control of supply. However, disadvantages include resources spent on labor, irrigation and pest control. Advantages to collection from the wild include free and open access. Disadvantages include long distances, extended time in the field, and dangerous locations.

Assuming that a particular plant species grows in abundance in the highlands and considering that vendors typically do not prefer to cultivate medicinal plants, it becomes important to consider what would happen if the availability of a particular species were to diminish in its natural habitat. Over-harvesting may become an issue as demand for traditional healing and medicinal plants rises. In addition, pressure on natural resources and activities such as agriculture and mining are issues of escalating concern in $\mathrm{Ca}$ jamarca. These potentially threaten the habitats of plant species traditionally used for medicinal purposes.

The situation that this study describes in which the dominant species are available in the marketplace with little focus on cultivation of medicinal plants has important implications in terms of habitat conservation. It shows that the typical use of homemade remedies depends on introduced instead of native species and that people are dependent to a significant degree on the habitats in which native medicinal plant species grow. To date, there has been little academic research on the habitat requirements and regeneration potential of many plant species of medical value that are native to the Peruvian highlands.

\section{Conclusions}

Pressure for natural resources is an issue of escalating concern in Cajamarca, as it is in many regions of Peru. Where these activities encroach upon the habitats of particular native species, the results of this study pose the question whether local people will respond by cultivating medicinal plant species to preserve their availability and use or whether the availability of these species will gradu- ally decline. More research needs to be done on habitat requirements and regeneration potential of medicinal plant species in Cajamarca. The preservation of native plant species and the habitats from which they come is highly dependent on current market demand and harvesting practices.

\section{Acknowledgements}

The authors gratefully acknowledge the financial support of fieldwork by MIRT (Minority International Research and Training) and MHIRT (Minority Health Disparity International Research and Training), a grant from the National Institutes of Health (Fund: 54112B MHIRT Program, Grant: G0000613), administered by the Fogarty International Center for Advanced Studies in Washington, D.C. We thank Doña Julia, Don Santo, Don Emílio, Doña Andrea, and Señora Esperanza Viva for their warmth, hospitality and contributions to the research. We also thank Doña Santos and Doña Durma for sharing their knowledge and experiences.

\section{Literature Cited}

Alcorn, J.B. 1992. Indigenous agroforestry systems in the Latin American tropics. Pp. 203-218 in Agroecology and Small Farm Development. Edited by M.A. Altieri \& S.B. Hecht. CRC Press, Boston.

Brako, L. \& J.L. Zarucchi. 1993. Editors of Catalogue of the Flowering Plants and Gymnosperms of Peru. Missouri Botanical Garden Press, St. Louis, Missouri.

Bussmann, R.W. \& D. Sharon. 2006. Traditional plant use in Northern Peru: Tracking two thousand years of health culture. Journal of Ethnobiology and Ethnomedicine 2:47.

Colunga-García Marín, P. \& D. Zizumbo-Villarreal. 2004. Domestication of plants in Maya lowlands. Economic Botany 58(Supplement):101-110.

Coomes, O.T. \& N. Ban. 2004. Cultivated plant species diversity in home gardens of an Amazonian peasant village in northeastern Peru. Economic Botany 58:420-434.

Eyzaguirre, P.B. \& O.F. Linares. 2004. Editors of Home Gardens and Agrobiodiversity. Smithsonian Books, Washington D.C.

Major, J., C.R. Clement \& A. DiTommaso. 2005. Influence of market orientation on food plant diversity of farms located on Amazonian dark earth in the region of Manaus, Amazonas, Brazil. Economic Botany 59:77-86.

McBride, J.F. 1936-1981 Editor of Flora of Peru. Fieldiana: Botany. Field Museum of Natural History, Chicago. 


\section{Bussmann et al. - From garden to market? The cultivation of native and introduced medicinal plant species in Cajamarca, Peru}

Merrick, L.C. 1992. Crop genetic diversity and its conservation in traditional agroecosystems. Pp. 3-11 in Agroecology and Small Farm Development. Edited by M.A. Altieri \& S.B. Hecht. CRC Press, Boston.

Shanley, P. \& N.A. Rosa. 2004. Eroding knowledge: An ethnobotanical inventory in eastern Amazonia's logging frontier. Economic Botany 58:135-160.

Smith, N.J.H. 1996. Home gardens as a springboard for agroforestry development in Amazonia. Tree Crops Journal 9:11-30. 
